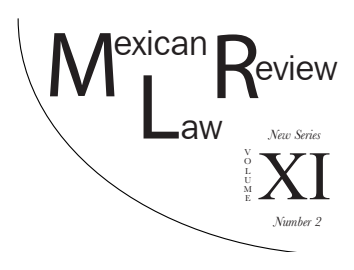

\title{
TOWARDS A GLOBAL INTERNATIONAL FAMILY MEDIATION PROGRAM: THE PROFILE OF A MEDIATOR IN MEXICO
}

\author{
Nuria GonZÁLez MarTíN*
}

\begin{abstract}
This note is a brief analysis on one of the most recent developments of the work initiated by the International Social Service, ISS, in order to create a global international family mediation program that will transition from a collaborative process into an international network of specialized mediators, where a mediator profile is fundamental. The author of this article was part of the ISS group that convened in Geneva in May, 2017.
\end{abstract}

Keywords: Alternative Dispute Resolution; Mediation; Collaborative Process; International Network; Profile of International Mediators.

Resumen: Esta contribución es una breve presentación en torno al desarrollo más reciente iniciado por los Servicios Sociales Internacionales, ISS, con el objeto de crear un programa global de mediación familiar internacional que transita desde un proceso colaborativo hasta la creación de una red internacional de mediadores especializados donde el perfil del mediador es fundamental. La autora de la presente nota formó parte de este grupo reunido en Ginebra en mayo de 2017.

Palabras clave: Medios Alternos de Solución de Conflictos; mediación; proceso colaborativo; red internacional; perfil del mediador internacional.

* Senior Researcher, Institute for Legal Research, UNAM, PhD in Private International Law, Pablo de Olavide University, Seville. Spain. Visiting Scholar and Fellow, Stanford Law School 2012-2016 and 2017-2018. External counselor to Mexico's Foreign Affairs Ministry on Private International Law. Family, Civil and Commerce law mediator certified by Mexico City's High Court. This contribution was written during my sabbatical year at Stanford University with the support of Programa de Apoyos para la Superación del Personal Académico de la UNAM, PASPA-DGAPA, UNAM, 2017-2018. Email: nuria.gonzalez68@gmail.com. 
Esta revista forma parte del acervo de la Biblioteca Jurídica Virtual del Instituto de Investigaciones Jurídicas de la UNAM http://www.juridicas.unam.mx/ https://biblio.juridicas.unam.mx/bjv https://revistas.juridicas.unam.mx/ http://dx.doi.org/10.22201/iij.24485306e.2019.1.13132

Table of Gontents

I. INTRODUCTION 176

II. A Description of Mediation in Mexico. 178 Annex: ISS Preparation Sheet: The Profile of a Mediator in Mexico. 182

\section{INTRODUCTION}

In 2010, the International Social Service (ISS), an international organization that assists children and families confronted with complex social problems as a result of migration, ${ }^{1}$ created a global International Family Mediation (IFM) program ${ }^{2}$ made up of diverse senior experts in cross-border family disputes. ${ }^{3}$ This program is aimed at better protecting children involved in parental conflicts across national borders by facilitating access to mediation for families, uniting mediators from around the world, and working towards global recognition of their capabilities. ${ }^{4}$

The ISS has been a consistent leader in the discussion around how mediation can be used to assist families, its goal is to establish and promote IFM worldwide $^{5}$ and for this reason, from the outset, one focus has been on pro-

1 ISS is an international NGO composed of 120 national entities assisting children and families confronted with complex social problems across borders. ISS is a global actor in promoting child protection and welfare, helping approximately 75,000 families around the world each year. ISS members carry out training projects, awareness raising and advocacy work in an effort to better respect children's rights.

2 The International Family Mediation program aims to better protect children involved in parental conflicts across national borders, and is involved in cases of international child abduction, which are steadily increasing.

3 The program's key objectives are to: 1. Provide reliable information to the three target audiences of cross-border conflicts (families, psycho-social and legal professionals supporting families, and policy makers and government authorities); 2. Raise awareness of the benefits and limits of mediation among these actors, towards the prevention of child abduction; and 3. Support the formalization of cross-border family mediation by bringing together professional networks to discuss qualifications, disseminate information and facilitate access to specialized family mediators.

4 The ISS General Secretariat undertook an evaluation of its International Family Mediation program with the objective of better informing decisions regarding the future of the program, specifically regarding the program's general direction, scope and the resources required.

5 The IFM's initial program is composed of five pilot projects between 2011 and 2018. These pilot projects are: 1. Drafting, publication and dissemination of a multilingual guide for families and supporting professionals, translated into 9 languages (completed in 2014); 2. Adaptation of the Guide to an online format, multilingual (5 languages) and complemented by a directory by country with human resources in support of parents and professionals involved in cross-border family conflicts (completed in 2016); 3. Drafting and publication of the "Charter for International Family Mediation Processes," and a "How to Use" booklet intended for authori- 
ducing comprehensive IFM materials and tools in multiple languages. A good example of this is "Resolving Family Conflicts: A Guide to International Family Mediation."

In Geneva, Switzerland, on October 21, 22 and 23, of 2015, two related academic events were held under the auspices of the Hague Conference on Private International Law, International Social Services (ISS) and the University of Geneva, among others, called "Cross Border Child Protection. Conference and Workshop."

The first event was called "Cross Border Child Protection: Legal and Social Perspectives - Towards Better Protection of Children Worldwide - The 1996 Hague Child Protection Convention in Practice," which gathered more than 190 experts from various regions of the world. The second event was a workshop called "Consultation on the Charter for International Family Mediation Processes," which convened 52 mediators specializing in international family mediation. ${ }^{7}$ In 2016, continuing with its global IFM program, the ISS published the "Charter for International Family Mediation Processes," also known as the First Meeting: The Charter. ${ }^{8}$ In 2017 this collaboration continued with the aim of creating a Global Network International Family Mediators (The Network), this is also referred to as the Second Meeting: Towards a Global Network of Specialized Mediators. Its conclusions will be presented in 2018 and its action plan spans two to three years. ${ }^{9}$

The Network, which involves both individual mediators and recognized regional and transregional organizations, paves the way to promote and strengthen IFM practice across regions and countries, and to facilitate access

ties, put together through a collaborative process on the part of mediation practitioners from all continents in three languages (completed in 2017); 4. Creation of an interactive platform for professionals, to share best practices and advance advocacy efforts for International Family Mediation (Scheduled to be completed in June 2018); 5. Creation of a global network of International Family Mediators (Scheduled to be completed in October 2018). See also the "Terms of Reference" of the evaluation of the ISS Global Program on International Family Mediation.

6 A guide aimed at families and professionals in the field, published in 2014 and translated into 9 languages. This guide has several strengths, particularly that it is faithful to the legislation on the matter and attends to the emotional effects that the abduction of children causes for all the members of the family. The Guide was published in 2014. See: wrerr.iss-usa.org.

7 The author of this paper was invited to participate as an international family mediator.

8 For ISS, The Charter is at the core of cross-border family mediation. In the words of Cilgia Caratsch, Coordinator of the ISS Mediation Unit, The Charter, the key ideas over the middle and long term were to: 1 . Implement the 10 principles, including in regions/countries where mediation is currently developing; 2. Be an incentive for training initiatives, or training modules, to propose methods and curricula to train family mediators towards the respect of the 10 principles; and 3. Reinforce cooperation between mediation practitioners and authorities in each region and country. See: wrere.ifm-fmi.org.

9 ISS-ISI, Vers la Création d'un Réseau Global de Médiateurs Familiaux Internationaux, (2017), available at werere.iss-ssi.org/images/MFI/fr/RAPPORT_FINAL_FR.pdf. 
to mediation for families and for the judiciary. ${ }^{10}$ The Network intends to help promote existing expertise and regional and transregional networks, as well as existing training offers, in order to expand professionalization and access to information for practitioners in different regions; ${ }^{11}$ it is not intended to duplicate already existing networks. ${ }^{12}$ A global group cannot promote a specific model of cross-border family mediation, rather the idea is to uphold the diversity of family mediation practice around the world. However, a global group can define strong and rigorous principles for cross-border mediation, which can be respected worldwide.

This note was prepared in order to explain the important steps forward in global mediation, in advance of second ISS meeting on the creation of an international network of specialized mediators that took place May 7 to May 9, 2017 in Geneva. This is part of a collaborative process/follow-up project that is part of the global international family mediation program initiated by ISS in $2010 .^{13}$

In what follows we present a description of mediation in $\mathrm{Mexico}^{14}$ in a manner that is consistent with the notes structure, emphasizing the general aspects of mediation in Mexico as well as the particular aspects of the profile of mediators in Mexico City, before concluding with an Annex containing a completed preparation sheet delivered at an ISS meeting.

\section{A Description of Mediation in Mexico}

Article 17 of the Constitution of Mexico establishes that "the law will consider alternative dispute resolution mechanisms." ${ }^{15}$ Mexico is a federation or-

\footnotetext{
10 ISS-ISI. "Terms of Reference Interim Steering Committee." wrwre.ifm-mfi.org.

11 Idem.
}

12 We are thinking, specifically, about MIKK, wrere.mikk-ev.de; Reunite, wrere.reunite.org or crossborderfamilymediator.eu, which promote the same model of cross-border family mediation, that is, at the core of all their endeavors (bilingual, bi-professional, male/female, co-mediation model). Certification is granted through participation in their own training initiative. Many mediators, other professionals and authorities dealing with cross-border family disputes around the world feel that this particular model is too costly and complicated to set up and for this reason, among others, the idea has arisen to create a Global Network that is more comprehensive in learning about knowledge and practice.

13 As we have mentioned elsewhere (missing citation) a good collaboration between different stakeholders is always necessary for international family mediation. Indeed, The Hague Conference on Private International Law $(\mathrm{HCCH})$ has always collaborated with organizations that have an important degree of specialization in the practical field. This is also the case with the ISS, and is part of the feedback that both organizations have been sharing during the last few years.

14 See also: Nuria González Martin, Mexico-US Cross-Border Family Mediation: Legal Issues in Mexico, 9 Mex.L.Rev. 129-139 (2017).

15 Constitución Política de los Estados Unidos Mexicanos [Const.], as amended June 18th 
ganized into 32 States, almost every one of which has legislative sovereignty over a significant number of matters, including the use of Alternative Dispute Resolution (ADR). In regards to legislation on ADR, all 32 states have laws in which the possibility of creating Alternative Justice Centers (AJC) is considered. Such AJCs would be located within the Supreme Court of each state. Family Law is a local matter, not federal. Thus, the 32 State Legal Codes would have to be amended, nonetheless, at present, there is a proposal for a Decree to add a fraction to Article 73 of the Mexican Constitution concerning ADR, so Congress could enact a General ADR Law. This law would then become compulsory for all states, as well as for the federation. The bill for a General Law on Alternative Dispute Resolution Mechanisms, issued on February $15^{\text {th }}, 2017$, does not deal with the issues that need to be addressed in order to accomplish the goals set by the constitutional reform, as no legal basis would be established to enable the plans contained in the Presidential Initiative. ${ }^{16}$

Mexico has no general rules guiding people who act as mediators; and while 31 states have specialized entities capable of providing ADR services (one of which is not fully operational, in Guerrero state); 27 states have formalized ADR policies in their local Congress. ${ }^{17}$ Most states only require that these facilitators be trained to steer mediation proceedings. However in other states like Mexico City, ${ }^{18}$ there are more specific requirements. ${ }^{19}$

In Mexico City there are three different types of mediators: Public Mediators, who are public servants that depend upon the Alternative Justice Cen-

2008, Diario Oficial de la Federación [D.O.], 5 de Febrero de 1917 (Mex.).

16 On December 12 $2^{\text {th }}, 2017$ the Parliamentary Gazette of the House of Representatives published the "Decreto por el que se expide la Ley General de Mecanismos Alternativos de Solución de Controversias y se reforman, derogan y adicionan diversas disposiciones del Código de Comercio, en materia de conciliación comercial."

17 Aguascalientes, Baja California, Campeche, Chiapas, Chihuahua, Mexico City, Coahuila, Colima, Durango, Mexico State, Michoacán, Guanajuato, Hidalgo, Jalisco, Nayarit, Nuevo León, Oaxaca, Puebla, Quintana Roo, San Luís Potosí, Sonora, Tabasco, Tamaulipas, Tlaxcala, Veracruz, Yucatán and Zacatecas.

18 In Mexico, nine states consider the mediator as the sole operator; 13 states regard operators as mediators as well as conciliators and in some cases even as arbiters; six states name the operator as a "specialist" or some other denomination; and nine states recognize private mediation.

19 For example, Aguascalientes requires that its mediators-conciliators have degrees in Law, Sociology, Education or any related social science. This also applies to private mediators. In Baja California Norte, specialists (mediators) must be college graduates, but does not specify any particular field. Baja California Sur has public and private mediators. In Campeche, mediators can be public or private, and must have a professional certificate (cédula profesional) in social sciences or humanities. In Chiapas mediators are public and independent specialists. They must have a professional certificate in social sciences (arbitrators must have a degree in law). In Jalisco, there are public and private mediators with only a professional certificate in an unspecified field. Tamaulipas does not require a college degree, but requires accreditation in mediation training, there is both public and private mediation. In Yucatán, mediators must have a professional certificate, but no mention is made of a particular degree, and there is also public and private mediation. 
ter of their corresponding jurisdictional authority; Certified Private Mediators, who are issued credentials and are supervised by the Alternative Justice Center of their jurisdictional authority; and Private Mediators, who act on a freelance basis. Public Mediation and Certified Private Mediation have the capacity to issue binding force regarding agreements and in the case of noncompliance mediation settlements are enforceable in Mexican federal court.

Article 18 of the Alternative Justice Law of the Mexico City High Court (MCHC) establishes the requirements to act as a public mediator:

To be a public mediator assigned to the Centre [it is necessary to]:

I. be a Mexican citizen in full exercise of his or her civil and political rights and be at least twenty-five years of age on the day of his or her appointment;

II. have a degree in law and a professional certificate, as well as a minimum of two years of provable professional experience in any of the matters under the jurisdiction of the Centre; ${ }^{20}$

III. apply and pass the corresponding selection process, taking exams and training courses $(\ldots)$

It should be noted that public mediators are non-union employees. Thus, mediators do not belong to the Courts' labor union. Mediators hold their position for three years. To be renewed for another three-year term, he or she must pass a work skills examination. The Mexico City Judicial Council is the body that ultimately decides whether a mediator can remain in his or her position.

Alternative Justice Center directors, as well as Court Officers who meet the legal requirements and receive the appropriate training, can be registered as mediators. Their status as public mediators must be ratified every three years and is lost upon leaving the Centre or not being a Court Officer, accordingly. In order to act as a mediator in criminal matters, Federal Law must be followed. Then there is the figure of private mediator, who is an individual trained to act as mediator who has received official certification to carry out mediation settlements. In order to practice, a mediator must be duly certified and registered by the Alternative Justice Centre in his or her state. Basically, a private mediator must fulfill the same requirements as those for a public mediator, he or she must hold a college degree (but not necessarily a law degree). However, private mediators must also comply with the conditions set forth in Article 18 of the Alternative Justice Law of the MCHC:

20 This is an issue we have repeatedly questioned in our papers (missing a reference) we feel that in a globalized world with the overwhelming mobility in which we are immersed, the requirement for a a professional certificate is unseemly. At the moment professional certificates are issued only for degrees obtained in Mexico. In this particular case, it applies to specifically to degrees in law and entails a drawn-out, tedious process that is incomprehensible and unattainable unless it is done through a writ of amparo. 
(...)

III. Have a good professional reputation and acknowledged integrity;

IV. Not have been convicted by a final judgment of an intentional crime that merits corporal punishment;

V. Take and pass an examination of work skills;

VI. Pass the training courses for certification and registration,

VII. Complete the practicum hours at the Centre as established in the Rules/ Regulations.

The certification and registration granted by the Centre will be valid for three years. To renew certification and registration, the work skills examination must be taken and passed. The provisions on the matter stipulated by the Rules and Regulations must also be met.

There is a creditable innovation in the legal reform of June 19, 2013, which states that public mediators who cease to be civil servants of the Court can be certified and registered as private mediators. Private mediators cannot handle criminal cases. In Mexico City, public mediators compete for their positions. They must take a course, and are tested by both the MCHC Institute of Legal Studies and the MCHC Alternative Justice Centre. The final decision on who will form part of the Centre as a mediator lies with the Mexico City Judicial Council, at the discretion of the General Director of the Centre. The public mediator attends those who use this service in turn; that is, the parties do not choose their mediator, but can refuse him/her if he or she has a conflict of interest in the case.

Private mediators take a 147-hour long diploma course jointly organized by the MCHC Alternative Justice Centre and the MCHC Institute of Legal Studies. All the applicants pass a diploma course and examinations before they can be certified and registered by the MCHC Alternative Justice Centre. They are evaluated and must complete 40 hours of practicum under the supervision of public mediators. ${ }^{21}$ According to Provisional Article 5 of the Decree of June 19, 2013, by which various provisions of the Alternative Justice Law of the MCHC were reformed, amended and repealed, private mediators with current certification and registration before the $\mathrm{MCHC}$ must take a training and refresher course in order to maintain their registration. ${ }^{22}$

By contrast, the choice of private mediator is open. Parties can choose the mediator who most appeals to them from an official list published in the MCHC Court Bulletin. Related to the 2011, 2013 and 2015 legal amendments, there are some new features regulating mediation that must be under-

21 Between 2009 and 2012, a 120-hour course was given at the MCHC Alternative Justice Centre with a 10-hour practicum instead of the above-mentioned diploma course.

22 See: Curso de capacitación y actualización para mediadores privados certificados [Training and updating course for certified private mediators] Boletín Judicial, Órgano Oficial del Tribunal Superior de Justicia del Distrito Federal, tomo CXCII, No. 152, September 10 2013, pp. 9-10 (Mex.). 
scored. Legally, mediation agreements are deemed as res judicata, forming part of an official record that can be annotated at the property registration office. The Law acknowledges that these agreements are comparable to judicial resolutions. Private mediation is well defined. Private mediators are considered assistants to the court and can certify the agreements settled by the parties (in public faith). They are no longer required to be lawyers as was previously required. In addition, some judicial clerks who execute judges' orders outside of the court can act as mediators. In Mexico City's High Court, the Alternative Justice Center is enabled to develop projects and programs in other social areas, not only regarding judicial matters. The Center may pursue this goal in collaboration with public and private institutions, which can be local or foreign. In addition, mediation may be used to prevent legal controversies. Finally, the law establishes that mediators may associate through colleges.

The supervision of Certified Private Mediation carried out by Alternate Justice Centers includes:

- Managing the records and files of the mediators;

- Randomly monitoring and verifying mediation services either by default or due to a complaint filed against a private mediator;

- Revising and, if appropriate, recording mediation agreements;

- Determining whether mediators require psychological support as a result of their constant exposure to human conflict;

- Conducting quality of service surveys among mediated parties upon process completion.

\section{Annex: ISS Preparation Sheet: The Profile of a Mediator in Mexico}

Please briefly describe for, and inform the audience about the most common context for your practice (where, with whom, under which circumstances):

The most common practice in Mexico is to run mediation processes in court-annexed programs. State courts have developed departments or Alternative Justice Centers which are in charge of these programs. Paradoxically, Judges do not usually encourage the parties to try mediation. Most people who use mediation do so because other people have recommended that they try this method as an effective way of solving problems. Mediation is not mandatory in Mexico.

Do you work in huge cities or more remote places; with different kinds of families or those that live under similar social circumstances with similar problems and conflicts; in contexts or situations such as migration or armed conflict? 
In Mexico, we mediate in large and small cities as well as in rural communities. Many types of families have undergone mediation processes: single parents, gay or lesbian couples, married or unmarried, etc. We understand family as a complex organization composed by several individuals recognized as such by law.

What are the main type of issues that you mediate?

Child custody, child maintenance support, alimony, and family disputes in general. Mediation is used primarily to solve the same sort of disputes that are litigated in state courts, so long as the ordre publique is not affected.

Are agreements coming out of mediation mostly rendered legally binding?

We have not yet established mediation processes in Federal Law. In most states, mediation agreements do not only have binding force, they are considered res judicata.

Do you include children in mediation, or stress the child's perspective during mediation?

We have to analyse this on a case by case basis. Sometimes, exposing a child to a mediation process may be counterproductive and contrary to that child's best interest. Children's interests are always considered, even if they do not participate in the process.

Do you include extended family, community or religious leaders, or any other third parties (e.g. representatives of welfare services) in mediation?

As above, we have to analyse this on a case by case basis. In restorative practices it is more common to call stakeholders into the process.

Please, give an example of how you conduct mediation.

- Introduction;

- Listen to the parties;

- Screen the case for suitability;

- Ask parties for their consent.

- Explain the ground rules that must be followed in a mediation process.

- Move parties from positions to their interests;

- Explore possible solutions (Brainstorming);

- Reality check the feasibility of their proposals;

- Reach an agreement.

Where do you mediate (premises)? 
Basically inside of courts, but not in the same space where trial hearings take place. As mentioned, we have built specialized infrastructure for mediation sessions called Alternative Justice Centers (AJC).

Do you have access to a good internet connection or other communication technologies (to potentially conduct mediation at distance)?

Only in wealthier states, but even in these states some mediation centers located in rural communities or in impoverished urban places do not have access to the internet, much less internet that is reliable and high speed.

Do you need to travel to conduct mediations, and who would pay for it?

Travel expenses, if any, are usually covered by the parties. There is also a desire to implement or encourage online dispute resolution.

Do you use co-mediation; and caucuses?

Yes.

Do you proceed to screenings for suitability, and if yes, how you do them?

Yes. The screening process includes, but is not limited to the following: the mediator has to be sure that the dispute is not contrary to the ordre publique; that the parties are willing to participate in the process voluntarily, and to show the parties their BATNA (Best Alternative to a Negotiated Agreement).

What is your relationship with authorities?

As a Certified Private Mediator and External Counselor at the Mexican Ministry of Foreign Affairs, I have an excellent personal relationship with the Mexican federal authorities. As Certified Private Mediators, our relationship with judges is informal, since they can recommend mediation to the parties, but there is no mandatory mediation in Mexico. A formal relationship is established with courts once the mediation agreement, which is deemed to be res judicata, is achieved and presented for execution.

Please briefly discuss which principles in The Charter are the most challenging to maintain?

First, decision making by the participants. Recently in Mexico, there has been an increasing trend of simulating mediation processes. People can easily become certified as mediators, but they generally lack supervision. At the end of the day these "mediators" (who are basically lawyers) essentially sell judicial resolutions (mediation agreements are res judicata) to the parties. They give advice to the parties regarding what they deem to be best for themselves. This simulation is dangerous. 
Second, the qualification of International Family Mediators. Very little has been done in Mexico on this point. Currently just one state has had training (carried out by myself) in International Family Mediation. There is a lot of work to be done in this area.

Third, developing the cultural awareness and sensitivity of mediators. Only some mediators in states with a strong presence of Indigenous people have developed certain degree of cultural awareness and sensibility. There is a lot of work to be done on this issue, especially in International Family Mediation, as we sometimes must do bi-cultural mediations.

What makes you competent and qualified in your practice and/or in your country?

Is it training?

Yes.

Is it an accreditation or certification?

Yes.

Is it your personal experience and skills?

No, but these should be taken into consideration.

Is it an appointment from a Ministry or another authority or public service? No.

Are you utilising The Charter in your practice in any way, including sharing it with authorities or persons coming to mediation; could The Charter add to your qualification (if you undersigned it)?

I trained Public Mediators to be certified in International Family Mediation and The Charter was a key tool. First it was introduced to the mediators to become acquainted with it, later I required that it be used in their practice. Mediators thus trained will in turn certify others using The Charter. In parallel, The Charter is being distributed to Mexican federal authorities and designated judges who work on International Parental Child Abduction.

Please describe one aspect of your practice which you find particularly effective.

Decision making by the parties. The mediator is best viewed as a facilitator who helps the parties to improve their communication skills and their negotiating approach. If the agreement is the result of the most intimate conviction of the parties, the likelihood of compliance is very high. If a third party intervenes excessively, the likelihood of compliance diminishes drastically. 